\title{
The Trans-Pacific Lend-Lease Shuttle to the Russian Far East 1941-46
}

\author{
Jan Drent
}

Le soutien accordé à l'URSS en vertu du prêt-bail américain et de l'aide mutuelle canadienne pendant la Seconde Guerre mondiale a été en grande partie ignoré par les historiens. S'appuyant sur les vastes ressources archivistiques situées à Ottawa et à Washington, cet article décrit les travaux visant à fournir à l'URSS, par la route $d u$ Pacifique Nord, la moitié des approvisionnements qu'elle a reçus des États-Unis au cours de la guerre. L'article traite notamment des défis de l'environnement, de la route et ses difficultés de navigation et de logistique, de l'organisation de la voie de ravitaillement du prêt-bail aux États-Unis et de la fourniture et la réparation de navires, dont plusieurs étaient dangereusement susceptibles aux fissures.

Since Soviet Russia is the decisive factor in the war, she must be given every assistance and every effort must be made to obtain her friendship. Likewise, since without question she will dominate Europe on the defeat of the Nazis, it is even more essential to develop and maintain the most friendly relations with Russia. - President Roosevelt's Soviet Protocol Committee, August $1943^{I}$

The story of Lend-Lease became a victim of the Cold War. ${ }^{2}$

\section{Introduction}

The extraordinary transport of over nine million long tons of cargo across the North Pacific between 1941 and 1945 to assist the USSR is little known because it was

\footnotetext{
${ }^{1}$ Dwight Tuttle, Harry L. Hopkins and Anglo-American-Soviet Relations 1941-1945 (New York: Dissertations-G, 1983), 105.

${ }^{2}$ Richard Overy, Russia's War 1941-1945, (New York: Penguin Books, 1998, paperback), 195.
}

The Northern Mariner/Le marin du nord, XXVII, No. 1 (Jan. 2017), 31-58. 
largely ignored by both the Americans and the Russians during the Cold War. ${ }^{3}$ Under the Lend-Lease program the United States provided food, oil and material to the Soviet Union, locked in desperate struggle with Germany. Canada operated a similar program termed Mutual Aid. Half of the tonnage shipped to the USSR by the United States under Lend-Lease was shuttled to the Russian Far East in Sovietoperated vessels from US, and later Canadian, west coast ports. ${ }^{4}$

This paper will describe the geopolitical context, the overall organization of the shipments, the navigational challenges posed by geography and climate, the infrastructure at both ends of the shuttle, the ships and crews, and the cargoes transported. It includes new information, in particular the fact that military supplies were included from mid-1943 onwards. The Soviet shipmasters were interviewed about their voyages by US and Canadian Boarding Officers. There are extensive collections of these reports, along with other files about the organization of the North American end of the shuttle, in the national archives in Washington and Ottawa. ${ }^{5}$ This paper is based on comprehensive research in these archives, an authoritative post-Soviet Russian study, ${ }^{6}$ and on published books and articles including sailing directions and other hydrographic publications.

\footnotetext{
${ }^{3}$ The writer wishes to acknowledge that Ole Heggen and Emily Thiessen of Victoria produced the graphics and Martin Bollinger of Fairfax, Virginia who provided the original spur to analyse the transpacific shuttle.

${ }^{4}$ The North Pacific was one of the three lengthy sea routes available from North America. The two other routes each accounted for one quarter of the total shipments. The North Russia route was vulnerable to German attacks; the Persian Gulf route necessitated development of port and rail infrastructure in Persia (Iran), Iraq and the USSR and was plagued by congestion. The total shipped was 17,501,000 tons: 49.6 percent Russian Far East \& Siberia; 23.7 percent Persian Gulf and 22.6 percent North Russia. Robert H. Jones, The Roads to Russia (Norman, OK: University of Oklahoma Press, 1969), 290.

5 The surviving records are rich in detail. Particularly useful are a total of thirty-three summary reports produced between 1943 and 1946 by the RCN's Directorate of Naval Intelligence which pull together information in reports on individual ship visits by US and Canadian Boarding Officers, along with summaries of sailings from each port. Despite constraints on how freely Soviet captains spoke an impressive amount of detail was accumulated over hundreds of interviews about weather and ice, encounters with Japanese patrols, and unloading times. Twenty-four of the thirtythree summaries are in LAC, RG24. Their title, "Report of Interrogation of Masters," is misleading because they were based on interviews during which the naval reservist boarding officers, including native speakers, tried to establish a tone conducive to openness. There are extensive additional contemporary documents at both the National Archives and Records Administration (NARA), College Park, Maryland, and the Library and Archives Canada (LAC), Ottawa.

${ }^{6}$ Alla Paperno, Tayni I Istoria: Lend-Liz Tixii Okean [Secrets and History: Pacific Lend-Lease] (Moscow, 1998), 18, 214-5. This work is based on extensive interviews with Russian mariners and published works describing Lend-Lease voyages. When the USSR collapsed there was intense interest in topics long suppressed; Alla Paperno, a scientist who had lived in the Russian Far East for several years discovered that the massive wartime Lend-Lease imports were not being acknowledged in local museums and conferences about the war years. She was determined to shine light on the wartime transpacific voyages and spent several years compiling her authoritative study.
} 


\section{Lend Lease and the Geopolitical Context}

When Germany attacked the Soviet Union in June 1941 the United States was still neutral. President Roosevelt moved quickly to lift legal impediments to trade with the USSR, which requested almost $\$ 1.8$ billion in aid, including aviation fuel. The logistic challenges in delivering supplies from North America to Russia were staggering. The three available sea routes all involved long voyages and the transpacific track passed close to Japan. The purchases were initially to be paid for by Russia whose ready financial resources were soon exhausted. The US administration set up machinery to expedite assistance, providing loans against future "advances" of gold and raw materials. In early November the USSR was formally included in the Lend-Lease program which had been established that March. ${ }^{7}$ The administration of Lend-Lease aid to the USSR came to involve several agencies. President Roosevelt gave the program high priority from the outset, assigned high level responsibility to his trusted official, Harry Hopkins, and maintained close interest in progress and bottlenecks throughout. ${ }^{8}$ There were four successive formal protocols signed between the two countries (1941, 1942, 1943 and 1944; Canada was also a signatory to the 1943 and 1944 protocols) to formalize detailed aid requests from the Russians. Government structures evolved to deal with setting priorities and arranging procurement. It became obvious within months that departments and agencies had overlapping responsibilities. An inter-departmental group called “The President's Soviet Protocol Committee," initially under Hopkins, was formally established in October 1942. Its responsibilities included the formulation and administration of the Soviet aid program, including the coordination of shipping. ${ }^{9}$ It gave policy direction to the expanding Lend-Lease bureaucracy. The Russians had established their own organization, the Soviet Purchasing Commission, in the United States in February 1942 which negotiated with government departments and agencies about actual purchases funded under the successive protocols.

The geopolitics were complex because Japan had concluded a Neutrality Pact with the USSR in April 1941. ${ }^{10}$ Even though the USA and Canada were at war after December 1941 with both Japan and its ally Germany, Japan allowed vessels

\footnotetext{
${ }^{7}$ Hubert P. van Tuyll, Feeding the Bear American Aid to the Soviet Union 1941-1945 (New York: Greenwood Press, 1989), 4-5. The Lend-Lease Act authorized the President to approve assistance to any country whose defeat would endanger the US Britain was the first country designated.

${ }^{8}$ Jones, The Roads to Russia, cites several presidential directives 88-89; Emory S. Land, Winning the War With Ships (New York: Robert M. McBride Co., 1958), 224. Admiral Land, an old associate of Roosevelt's, was simultaneously chairman of the US Maritime Commission and the War Shipping Administration. He cites several directives which demonstrate the presidents' ongoing attention to shipping issues.

${ }^{9}$ Richard M. Leighton and Robert W. Coakley Global Logistics and Strategy 1940-43

(Washington, DC: Office of Chief of Military History, 1955), 560.

${ }^{10}$ George Lensen, The Strange Neutrality. Soviet-Japanese Relations during the Second World War (Tallahassee, FL: Diplomatic Press, 1972), 33.
} 


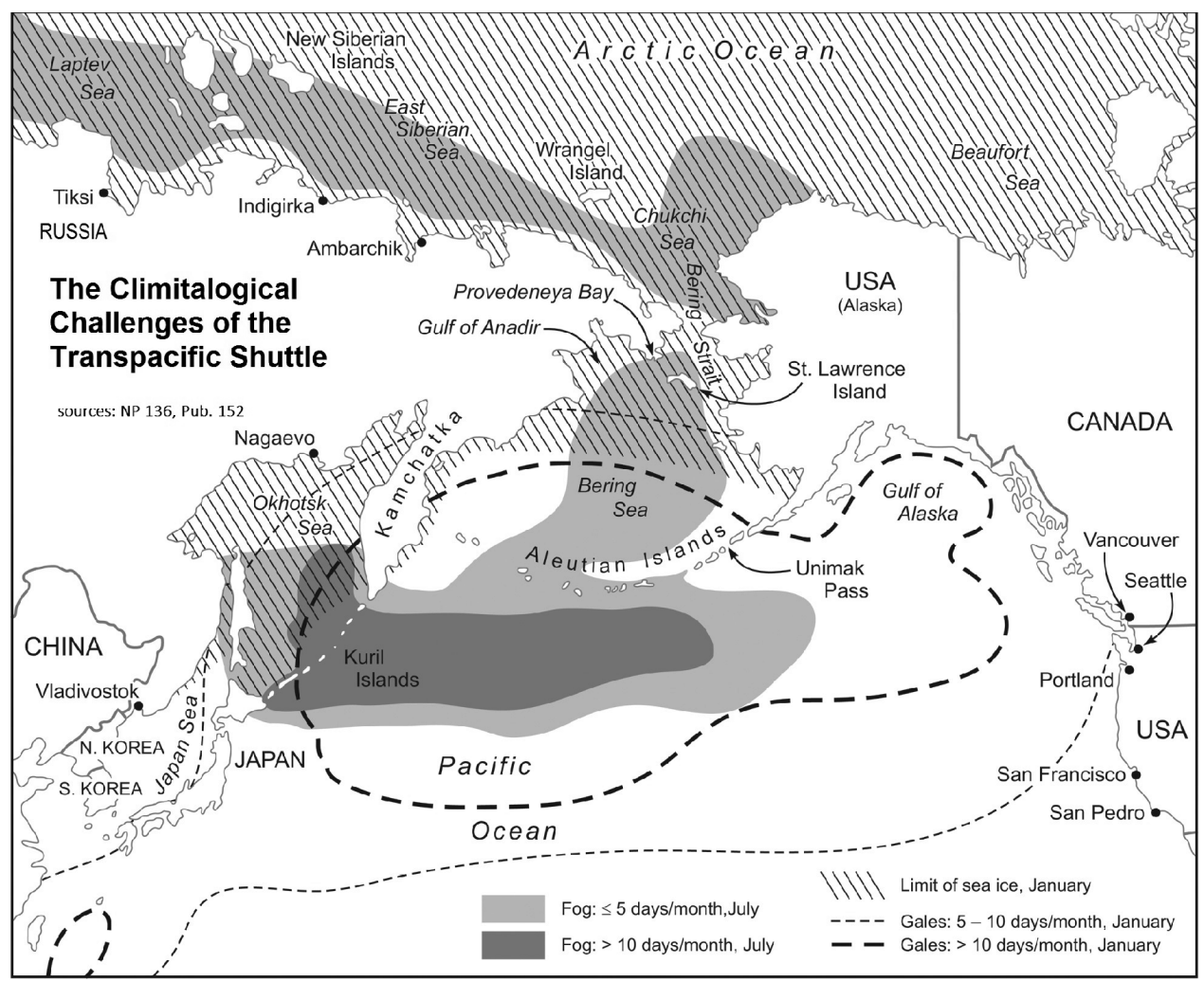

provided by the Americans to carry Lend-Lease supplies through its archipelago to Russia. ${ }^{11}$ Trans-Pacific shipments were initially restricted to non-military cargoes to avoid Japanese interference on the basis that the import of war supplies by the Soviets could be regarded as an unfriendly act. The archival records show however that military items were shipped across the Pacific from mid-1943 onwards. Because both Japan and Soviet Russia had strategic reasons to avoid hostilities with each other they maintained strained mutual neutrality until the USSR declared war in August 1945. ${ }^{12}$ The Japanese did not interfere with the flow of North American supplies through their home waters, and on the other hand the Soviets insisted that American aircraft being delivered to the Russian Far East be flown by Russian pilots. Russia also resisted American overtures to bomb Japan from its Far East.

Japan launched a series of diplomatic protests to the USSR even before the first aid from America arrived. The initial voyages across the Pacific in 1941 involved both US and Russian vessels. Japan protested as early as 20August about the

${ }^{11}$ German protests about Japan's neutrality with the USSR are described in, Gerhard Weinberg, $A$ World at Arms: A Global History of World War II (Cambridge: Cambridge University Press, 1994), 404.

${ }_{12}$ Weinberg, 404-405. 
expected sailing of an American tanker for Vladivostok, which arrived on 2 September ${ }^{13}$ and was in fact the first of seven from Los Angeles. ${ }^{14}$ The Soviets responded that goods being shipped from the USA were normal commercial transactions to compensate for the disruption of the Soviet economy by the German assault. This was the first of several similar Japanese protests, which were all met by robust Soviet responses stretching into $1944 .{ }^{15}$

\section{Environmental Challenges}

Gales, ice and poor visibility meant climatic conditions on the route were punishing. Soviet masters frequently reported having encountered force 11 and 12 storms in the northeast Pacific. ${ }^{16}$ In the words of the American Sailing Directions:

During most of the cool season (late fall, winter and early spring) the Gulf of Alaska has the highest frequency of extratropical cyclones in the Northern Hemisphere". Winter storms make "these waters the most active in the Northern Hemisphere. And with this activity comes the rain, sleet and snow, the howling gales, and the poor visibilities which characterize the weather along the northern great circle routes during this season. Gales can be expected 20 to 30 percent of the time north of a line from Japan to Vancouver Island. ${ }^{17}$

Ice was a seasonal hazard on the western portion of the shuttle route. In the classic prose of the Admiralty publication Ocean Passages For the World. From January to March the whole of the coastal waters of the Russian Maritime Province, the greater part of the Gulf of Tartary, Northern Hokkaido and the south-west Kuril Islands are encumbered with ice in varying degrees... Ice is also present in the vicinity of the north-eastern Kurils and along much of the east coast of Kamchatka and northward thereof." ${ }^{\prime 18}$ Finally, skies are overcast over the North Pacific for much

\footnotetext{
${ }^{13}$ The first British convoy delivering supplies to the USSR reached North Russia on 31 August 1941.

${ }^{14}$ Marty Bollinger, "Did a Soviet Merchant Ship Encounter the Pearl Harbor Strike Force?” US Naval War College Review (Autumn 2007), 98; Martin J. Bollinger, From the Revolution to the Cold War: A History of the Soviet Merchant Fleet from 1917 to 1950 (Windsor, UK: World Ship Society, 2012), 136-7. The first British convoy delivering supplies to the USSR reached North Russia on 31 August 1941.

${ }^{15}$ Lensen, 33.

${ }^{16}$ Kuban drifted for three days in force 12 (described in the Beaufort scale as "Hurricane") conditions in late November 1944; that season voyages normally requiring twelve days were taking eighteen to twenty-four. RCN Summary Report 13 Feb 45, 30, LAC, RG 24 Vol 8142, file 190-7 Vol. 1.

${ }^{17}$ Sailing Directions for the North Pacific Ocean (Bethesda, MD: Defence Mapping Agency, third edition, 1993), 2.29, 103

${ }_{18}$ Ocean Passages of the World (London: Hydrographic Department, Admiralty, 1950), 126.
} 


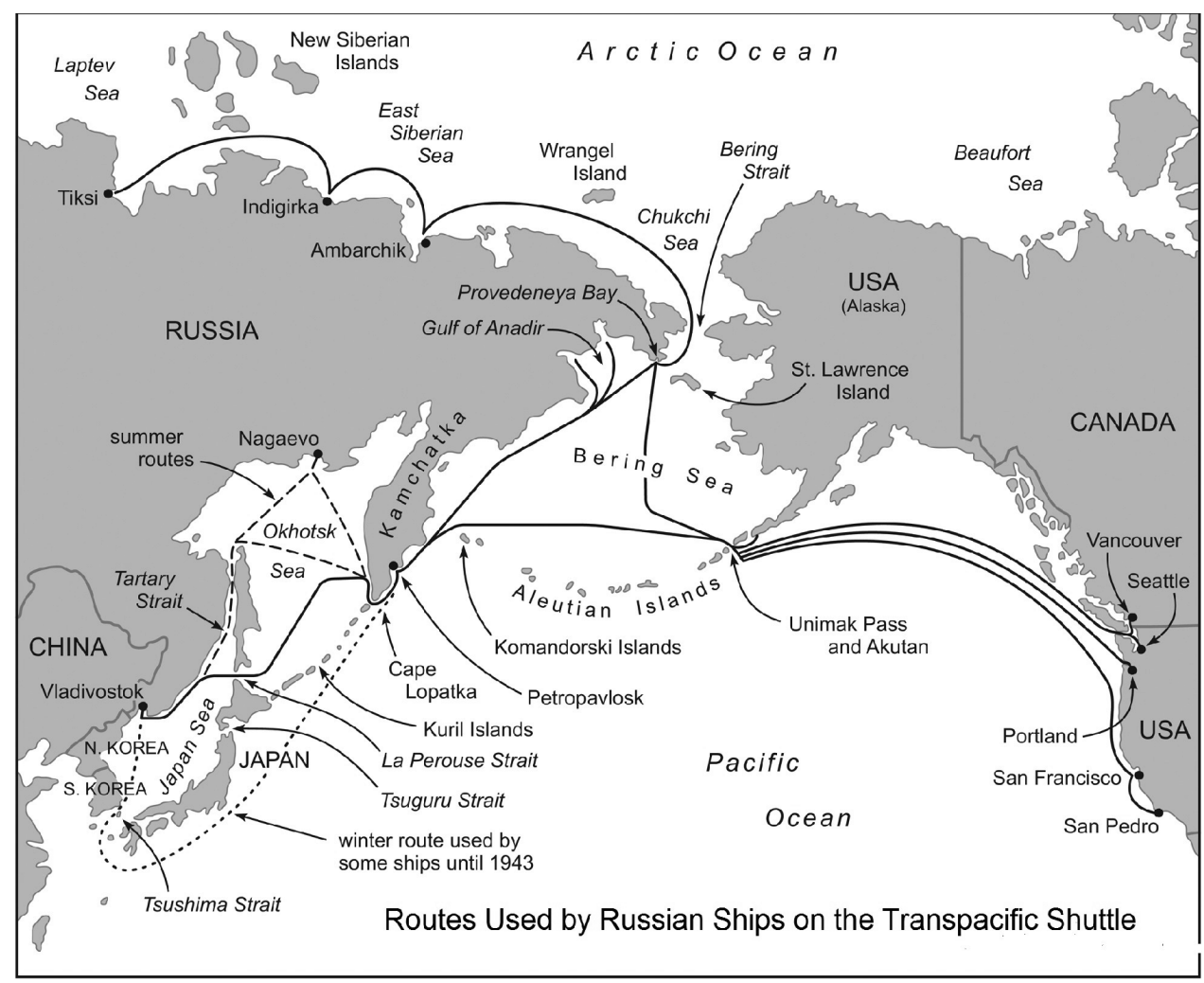

of the year north of $40^{\circ} \mathrm{N}$ (roughly the waters between northern California and Vladivostok). The debriefing reports are replete with reports of summer passages entirely or partially in fog, anchoring in straits because of zero visibility, etc. Visibilities of less or equal to $5 \mathrm{~nm}$ are encountered up to 20 percent of the time, with occurrences as high as 45 percent along the Kurile Islands, in the Sea of Okhotsk, and in the Bering Sea. ${ }^{19}$ Vladivostok has fog seventy-five days of the year; in June and July it occurs sixteen or more days each month. ${ }^{20}$

\section{The Trans-Pacific Shuttle Route}

The great circle route used across the ocean was some 4,500 nautical miles $(8,334$ $\mathrm{km}$ ) long. From the North Pacific it passed through the Aleutians at Unimak Pass at their eastern end. Tidal streams in Unimak are described in the Admiralty Sailing Directions as "considerable," with an average of 3 knots on both the ebb and flood

\footnotetext{
19 Sailing Direction North Pacific 2.28, 102; 2.29,103; 2.27,101.

${ }^{20}$ Bering Sea and Strait Pilot (Taunton, Somerset: UK Hydrographic Office, fifth edition, 1980), $62,6.112,252$
} 
at the narrowest part and up to $6-6 \frac{1}{2}$ during spring tides. ${ }^{21}$ This steep-cliffed island chain is frequently shrouded in fog but the US Coast and Geodetic Survey had fortuitously carried out extensive surveys in the thirties. ${ }^{22}$ Soviet freighters called in the Aleutians going in both directions for routeing instructions, and fuel if required, since stocks in the Russian Far East were limited. Until the fall of 1942 this stop was at the Naval Operating Base, Dutch Harbor, but in October the US Navy opened a fuelling base using an abandoned whaling station on Akutan Island east of Unimak Pass. ${ }^{23}$ An existing pier was rebuilt by Seabees, the US Naval Construction troops, and the former whale oil and fuel tanks were filled with bunker oil and diesel fuel. In early 1945 the Akutan station was closed and Dutch Harbor was again used. ${ }^{24}$ Soviet vessels similarly called for orders at Akhotmen Bay in Kamchatka, an anchorage twenty-seven nautical miles south of Petropavlovsk. By 1944 progress had been made to shorten delays at both ends of the shuttle, and some ships were now sailed directly from and to Vladivostok without calling in Kamchatka.

Beyond the Aleutians the prescribed tracks edged north of the Komandorski Islands in the Bering Sea, and skirted Kamchatka. Icefields could extend sixty to eighty miles off Kamchatka from January through part of April, and might also be encountered off the Komandorski Islands - on occasion fields extended right out from Kamchatka to the islands. ${ }^{25}$ One unlucky vessel spent thirty-two days caught in ice off Petropavlovsk in March 1945. ${ }^{26}$ The summer and winter tracks through the Sea of Okhotsk from Petropavlovsk to La Perouse Strait lay to the west of the Kuriles. The route entered the Sea of Okhotsk through the Pervyy Kurilskiy Prolivthe First Kuriles Strait between Kamchatka and the northernmost of the Japaneseheld Kuriles. This is wide and deep but tidal streams are strong; rates of 3.5 knots have been reported even at neap tides (the weakest tides each month). ${ }^{27}$

\footnotetext{
${ }^{21}$ Ibid., section 5.2

22 Gilbert T. Rude, "Our Last Frontier: The Coast and Geodetic Survey's Work in Alaska," The Geographical Review, 47: 3 (July 1957), 351.

${ }^{23}$ Colt Denfield, The Akutan Whaling and Naval Fueling Station: A History (n.p.: Alaska District, US Army Corps of Engineers, 1996). Dutch Harbor was the only naval operating base in the Aleutians. The Americans had forewarning of a Japanese attack in mid-1942 through signals intelligence. Japanese carrier aircraft bombed Dutch Harbor on June 3 and 4 and Japanese troops seized Attu and Kiska islands at the western end of the Aleutians on June 5 and 6 . There had apparently been instances when Russian freighters had not followed the proper identification drills when entering Dutch Harbor, and port facilities were limited. Shifting the fuelling stop for Russian ships to Akutan reduced problems now that Dutch Harbor was in an active war zone.

${ }^{24}$ Office of the Chief of Naval Operations Intelligence Report 31 Jan 45, para 10, NARA, RG $34 / 4$.

${ }^{25}$ RCN Naval Intelligence Division 2 (NID 2) Summary Report, 30 Jun 45, 30-31, LAC, RG 24, Vol 8142, file 11960-7 Vol 1.

${ }^{26}$ RCN Naval Intelligence Summary Report, 17 May 45, 26, LAC, RG 24, Vol 8142, file 1190-7 Vol 1.

${ }^{27}$ Japan Pilot (Taunton, Somserset: UK Hydrographic Office:, eighth edition, 2006), I:317. Neap tides occur when the moon is in its first and third quarter when it is not aligned with the sun.
} 


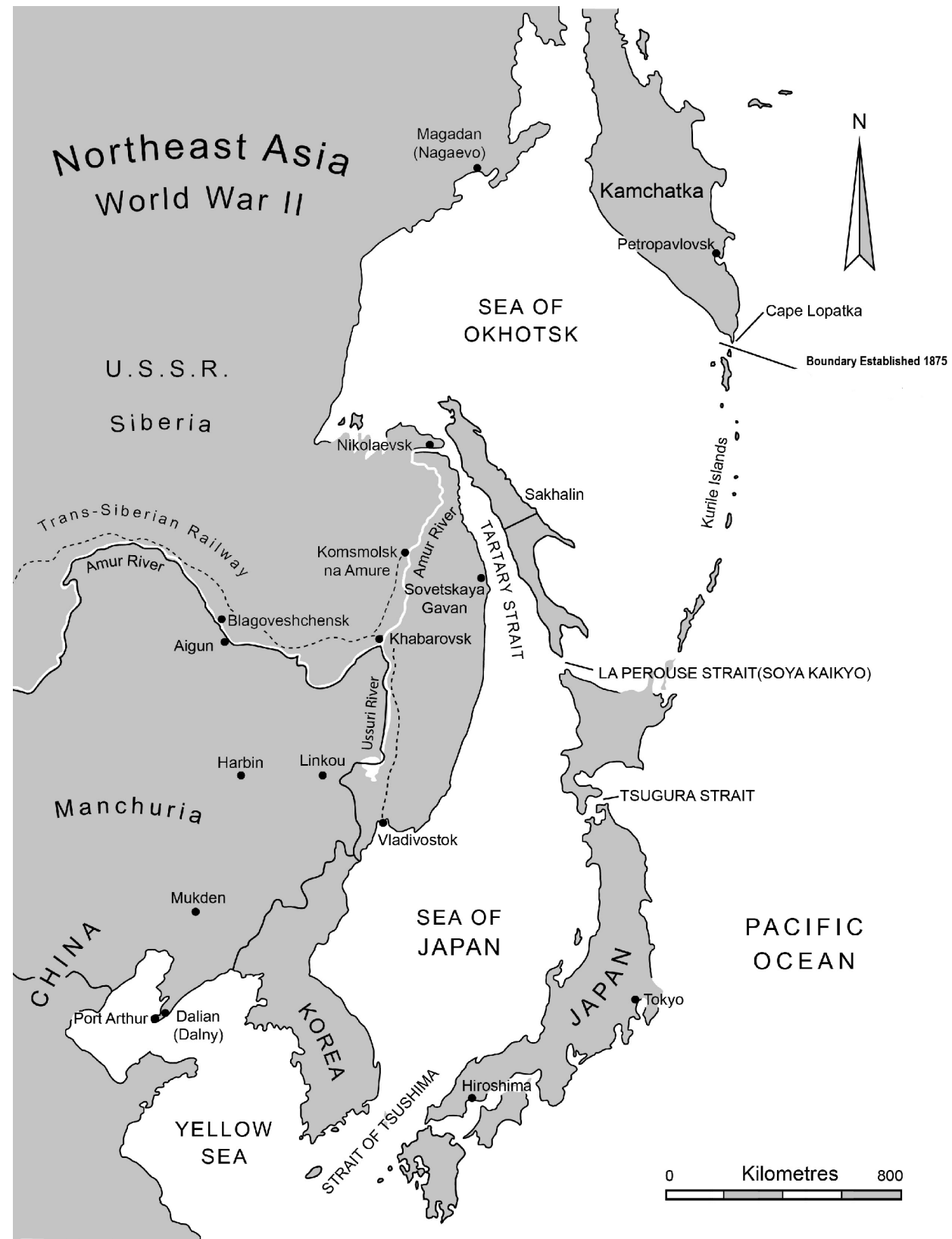

In the Sea of Okhotsk and west of Japan the shuttle route again passed through waters ice-infested for several months each year. Vladivostok, the western terminus of the shipments, is on the Sea of Japan. Access to the open Pacific is by one of four passages - three deep and one shallow. Two of the deep straits, Tsugaru and La 
Perouse (Soya), are through the Japanese archipelago. The ice-free Tsuguru is an international strait, and the most direct access from Vladivostok to the open Pacific, but was included as one of several "maritime defence areas" declared by Japan after initiating hostilities with the USA in December 1941. The USSR protested in late 1942 after vessels had been lost after being icebound in La Perouse Strait, but the Japanese remained adamant. ${ }^{28}$

La Perouse Strait, also an international waterway, is twenty-seven nautical miles (forty-three kilometres), wide at its narrowest point with tidal streams of 1.5 knots in summer. It was bounded by two Japanese islands since Southern Sakhalin on its northern side was held by Japan at the time. Russia had been guaranteed unimpeded navigation under the Treaty of Portsmouth in 1905. The Japanese prohibited passage during darkness, and to avoid minefields prescribed east and westbound tracks in a two-mile wide channel in the middle of the strait. ${ }^{29}$ Japanese patrol vessels in the strait challenged 178 Soviet vessels during the war and detained several, some for hours and some for months. ${ }^{30}$ By 1944 several Soviet masters were reporting that they were passing through the strait at night. Ice conditions varied from year to year, but this waterway was usually not passable without icebreaker assistance between mid- January and late March. Moreover, ice was present just to the east. Every winter some ships attempting La Perouse Strait became icebound for days- one vessel drifted for fifty-six days starting in February $1944 .{ }^{31}$ During the war Soviet icebreakers were refitted in the United States and Canada, and the Americans eventually transferred three powerful new ones. By January 1944 there were enough Russian icebreakers to escort "caravans" of up to eight ships through La Perouse Strait; that year the last such convoy was as late as mid-May. ${ }^{32}$ The freeze up starting in mid-January caused delays, and even though freighters made it through the ice with icebreaker assistance east and westbound ships accumulated in Petropavlovsk where not all cargo could be unloaded.

The Strait of Tsuhima, the third deep channel, involved a long passage around the south of Japan. This ice-free route was used if the first five months of 1942 by six of the eastbound sailings. In early 1943 it was also used once when La Perouse

\footnotetext{
${ }^{28}$ Lensen, 68-73.

29 Paperno, 37. After the war ended Russian minesweepers provided by the US carried out extensive sweeping operations against mines laid both by the Japanese and American submarines. Soviet freighters were permitted to go through the strait only preceded by one or two pairs of minesweepers. RCN Intelligence Summary 6 Feb 1946, 11, LAC, RG 24 Vol 8142 file 1480-7 Vol 2. The Japan Pilot (2006) still cautioned that the Strait was still open to navigation in daylight only due Second World War mines.

${ }^{30}$ Paperno, 16; one master reported that a Japanese boarding party used long rods to probe his cargo of grain, apparently suspecting that military cargo was at the bottom of the holds. Lensen, 60-68, describes Soviet diplomatic efforts to free captured vessels.

${ }^{31}$ RCN Naval Intelligence Summary 27 June 1944, 9, 10, LAC, RG 24 Vol 12010 file CNLO 7-21 Part 4.

${ }^{32}$ RCN Naval Intelligence Summary 27 April 1944, 20, LAC, RG 24 Vol 12070, file CNLO-7-2-1 part 4.
} 
Strait was blocked by ice. Further use was discontinued after two Soviet freighters were sunk south of Japan by an American submarine in February 1943 after coming out through the Strait of Tsushima. ${ }^{33}$

The shallow Strait of Tartary, the fourth passage, runs between Sakhalin and the mainland at the northern end of the Sea of Japan. Depths in this narrow passage were limited to 18 to 21 feet (5.5 to $6.4 \mathrm{~m}$ ) even with constant dredging. Its advantage was safety from Japanese intervention. It was also used to deliver cargo to Nikolaevsk, at the mouth of the Amur, and the newer port of Sovetskaya Gavan. ${ }^{34}$ Deep draught Liberty ships using the strait were lightened in Kamchatka or Nagaevo as required. ${ }^{35}$ The navigable season was however short and foggy, - from early June through October, when buoys were lifted. This was a difficult waterway as tidal streams are generally 2 to 3 knots, but can reach 5 knots, and the wartime buoyed channels through protective minefields were in places as narrow as $60 \mathrm{~m}$ (196 feet) ${ }^{36}$

Port development of Petropavlovsk on the southeast coast of Kamchatka facilitated by equipment and materials shipped from the United States is a noteworthy aspect of the Lend-Lease program. Petropavlovsk is strategically located near the great circle route to North America, but lacks rail or road connections with the rest of Russia. The harbour, at the head of a large bay which is a commodious anchorage, can be kept open in winter by light icebreakers. In 1941 it was primarily a small fishing port with a single wooden pier, no cargo handling cranes and very limited other infrastructure. The Russians decided in 1942 to develop its facilities because navigation though to Vladivostok became difficult during the winter months. This would help ease congestion in Vladivostok, and cargo could be unloaded in Petropavlovsk when access through the La Perouse Strait was blocked, enabling freighters to return across the Pacific. This freight could later be transported to the mainland in smaller vessels which were inefficient for the transPacific run. Eventually one-third of the cargoes that reached Vladivostok had been unloaded in Petropavlovsk, and subsequently shipped onward. ${ }^{37}$ An additional fueling point would also be advantageous as some of the Soviet freighters had limited endurance. Improvements were begun in 1943 using poorly-equipped convicts, and two wooden piers were completed that year. A more ambitious program utilizing cranes, bulldozers, excavators, compressors and concrete, all

\footnotetext{
${ }^{33}$ RCN Naval Intelligence Summary Report, 15 Jan 1944, 2, LAC, RG 24, Vol 12010, file CNLO 7-2-1 Part 4.

${ }^{34}$ CNO Naval Intelligence Division Intelligence Report 7 August 1943, 2, LAC, RG 24 Vol 12010 file CNLO 7-2-1 Part 4. Some of the first cargoes out of Vancouver included half-tracks listed as weapons carriers.

${ }^{35}$ RCN Naval Intelligence Summary 3 Sept 1943, 21, and 6 Oct 1943, 27; military cargoes from Vancouver BC starting 194315 Jan 1944, 22, and 11 July 1944, 2; all in LAC, RG 24 Vol 12010 file CNLO 7-2-1 Part 4.

${ }^{36}$ South and east Coasts of Korea, East Coast of Siberia and Sea of Okhotsk Pilot (Taunton, Somerset: UK Hydrographic Office, 2008), 10.7, 319; Paperno, 45.

${ }^{37}$ Paperno 62; 73.
} 
supplied under Lend-Lease, and twelve hundred soldiers commenced in October 1943. A pier with a 100-ton crane was completed by April 1944, and later that year three further piers and warehouses were built. By February 1945 a total of 6 new piers were in action.

Vladivostok on the Siberian mainland was the terminus of the railway to European Russia which carried Lend-Lease supplies westward 9,300km to European Russia. $^{38}$ Infrastructure at this major port was also expanded and improved during the war. In 1942 serious port congestion caused delays in unloading. Complaints from the Soviet Embassy in Washington presumably based on information received from the US War Shipping Administration prompted action. Seasoned managers were brought in from Moscow to improve cargo handling infrastructure. Port cranes were upgraded, and starting in 1942 a large warehouse complex was constructed 120 miles $(193 \mathrm{~km})$ from the city to ease congestion. Here shipments were sorted for further transport west by rail. ${ }^{39}$ The local population profited because their city was the destination of the Lend Lease shuttle. The American assistant naval attaché, who arrived there from serving in North Russia, reported in May 1943 that a great deal of American food was available, including unfamiliar items like dry cereals, tinned fancy grades of shrimp and crab, oysters and a poor grade of sugar. It was being traded in "gypsy markets" for potatoes, eggs and vodka. The population was being issued with quantities of American clothing especially cheap shoes. In September 1943 he reported that there were several bazaars in the city where goods were freely traded and bartered. "The principal reason for the existence of these markets is that there is a great influx of foreign goods contraband, and otherwise brought into the city from the United States by sailors. These goods are smuggled or cleared thru [sic] the port guards and customs, and then given to families, sweethearts and friends, [who] . . . when feeling the press for money or unobtainable food, take the gifts to the bazaar and barter them. " the black market, and in February 1945 a master and his chief officer were reportedly imprisoned for selling ship's stores. ${ }^{41}$ Stalinist Russia meted out harsh sentences to selected individuals convicted as "socialist wreckers".

Shipments of general supplies directly from the North American west coast to the Siberian Arctic began in the summer of 1942. Vessels first went north in the Bering Sea well to the west of American-controlled waters, and then called at Providenya on the Chutkoya Peninsula for voyage orders. They next anchored off ports at the mouths of rivers the Arctic coast, from where fuel and other items were

\footnotetext{
${ }^{38}$ Both Vladivostok and Vancouver were established in the 1860 and both became major ports strategically located at the ends of transcontinental railways. The trans-Siberian reached Vadivostok in 1897, while the Canadian Pacific Railway to Vancouver was completed in 1886.

39 Paperno, 50. The warehouse project, obviously assigned high priority, was launched in dreadful winter conditions.

40 "Intelligence Report by Assistant Naval Attaché Vladivostok," 6 May 43 and 14 Sep 43; NARA, RG 38/42.

${ }^{41}$ RCN Naval Intelligence Summary 13 Feb 45, 20, LAC, RG 25 Vol 8142 file 11961-7 Vol 1.
} 
loaded into barges to be shipped upriver. The westernmost port reached was Tiksi, at the mouth of the Lena $1,300 \mathrm{~nm}(2,400 \mathrm{~km})$ west of the easternmost extremity in Siberia with a navigation season of only two and a half months. Between 1942 and mid-1945 140 ships carried Lend-Lease cargoes from the US west coast to the Arctic. Lend-Lease aircraft - the total grew to a staggering 7,925 - were ferried by Russian pilots from Alaska starting in October 1942 using the ALSIB (Alaska Siberia) route. ${ }^{42}$ Lend-Lease supplies for this operation, and in particular aviation fuel, were transported inland from the Arctic Ocean by the Siberian rivers in the icefree months starting in 1943. One of the ALSIB fueling stops was in Yakutsk, a full $1,081 \mathrm{~nm}(1,730 \mathrm{~km} \mathrm{~km})$ up the Lena from Tiksi.

\section{Navigation, Voyage Lengths and Logistics}

The Soviet ships crossed the Pacific without electronic aids and gyrocompasses. They carried magnetic compasses, mechanical sounding machines and radio direction equipment. With celestial navigation often not feasible due to overcast skies careful dead reckoning and the use of soundings were essential. Strict radio silence was observed. Adherence to prescribed tracks was ordered to avoid attacks by friendly aircraft and submarines. Lighthouses and other navigation beacons in Soviet and Japanese waters were not operating. ${ }^{43}$ Some captains commented that the powerful Russian radio direction beacon on Cape Lopatka at the southern end of Kamchatka, which apparently could be used from a range of $300 \mathrm{~nm}$, was particularly useful. When war came in 1941 the Russians promptly laid minefields off the approaches to Vladivostok and Petropavlovsk as well as to the Tartary Strait. They created a new naval pilotage service to guide vessels through these areas. Pilotage stations were established in anchorages near the limits of the mined waters, in the case of Vladivostok at a distance of $132 \mathrm{~nm}(244 \mathrm{~km})$ up the coast. ${ }^{44}$

Overall voyage times and turnarounds varied greatly. The Pacific crossing generally took around twnety-one to thirty days, including stops off Kamchatka and in the Aleutians. In mid-1943 the US War Shipping Administration (WSA) estimated that a round voyage from the west coast and back varied between ninety days in summer to 115 in winter. Liberty ships averaged slightly longer, ninety-nine days. WSA officials attributed this to inefficient unloading in Soviet ports, but it probably reflects the volume of cargo carried in these ships, which were substantially larger than most of their counterparts. By mid-1944 four- fifths of the ships on the Shuttle were oil burners. ${ }^{45}$ Eastbound vessels normally bunkered with oil or coal in Nakhodka, a port eighty kilometres east of Vladivostok; this was also

\footnotetext{
${ }^{42}$ Jones, 112.

${ }_{43}^{43}$ Paperno, 110.

${ }^{44}$ Paperno, 24-46.

${ }^{45}$ Derived from CNO Intelligence Division Intelligence Report 1 July 1944, LAC, RG 24 Vol 6751 file S-NSS-8001-837.
} 
where oil hauled by tankers from the US unloaded. ${ }^{46}$ Coal was supplied to Petropavlovsk from Sakhalin, but deliveries were interrupted in the winter of 1944/45 by ice. In January 1945 it was reported that ten of twelve eastbound coal burning vessels reached Akutan "in dire need of coal"; one ship had been forced to burn wooden decking in her holds. ${ }^{47}$

\section{Organization of the Shuttle on the West Coast of North America}

The WSA had been created by the president in February 1942. This powerful new organization had a wide mandate to control US ocean-going and costal shipping. It was responsible for arranging the movement of cargoes to the ports of loading. The surviving records show that WSA officials were determined to improve loading times and to ensure an efficient flow of Lend-Lease cargoes. On the east and Gulf coasts the WSA allocated cargoes to individual, largely non-Soviet Allied freighters bound for the Persian Gulf or North Russia, which were then assigned to the convoy system. However on the west coast, as the shipping was Russian, it was the Soviets who consigned cargoes to individual vessels and were responsible for sailing their ships when loaded. They engaged a leading US shipping firm, Moore-McCormack Lines, as their west coast agents to arrange loading berths and stevedoring. Russian tankers loaded fuel primarily in Los Angeles, and after December 1944 in Seattle (which involved a shorter voyage). Freighters were initially loaded in Seattle, Portland, Tacoma and other west coast ports, but in 1943 the WSA mounted a campaign to discourage the use of San Francisco by Soviet vessels. It increasingly tried to funnel traffic through Portland, which was officially designated in August 1943 as the primary US terminus. ${ }^{48}$ Concentrating Soviet shipping in Portland had several advantages, including the fact that there were no major US naval installations which could become the target of intelligence gathering. ${ }^{49}$ Portland came to handle an increasing percentage of the cargoes shipped from US ports from 49 percent in 1943 to 66 percent in the first half of $1945 .^{50}$ Canada formally joined the Third Lend-Lease Protocol for providing supplies and war materials to

\footnotetext{
${ }^{46}$ A Russian master reported that large portions of the dock labour in Nakhodka were convicts and because they were "practically starving" there was considerable pilfering. RCN Intelligence Division Summary 22 Jan 1945, 22, LAC, RG 24 Vol 8142, file 11960-7-Vol 1,

${ }^{47}$ Eastbound ships were also low on provisions that winter and traded with ships arriving from North America. RCN Intelligence Summary 31 March 1945, 16, LAC, RG 24 Vol 8142 file 119617 Vol 1.

${ }^{48}$ CN0 Intelligence Division Intelligence Report 7 Aug 1943, 2 LAC, RG 24 Vol 6751 file S-NSS8001-837. Philadelphia was the East Coast primary port: Jones, 90.

${ }^{49}$ Correspondence between War Shipping Administration (WSA) officials in San Francisco and Portland March 24, 1943 and November 5, 1943, NARA, RG 248/31.

${ }^{50}$ Letter from Administrator War Shipping Administration Leo Crowley to Senator Morse, July 27, 1945, NARA, RG 248/22.
} 


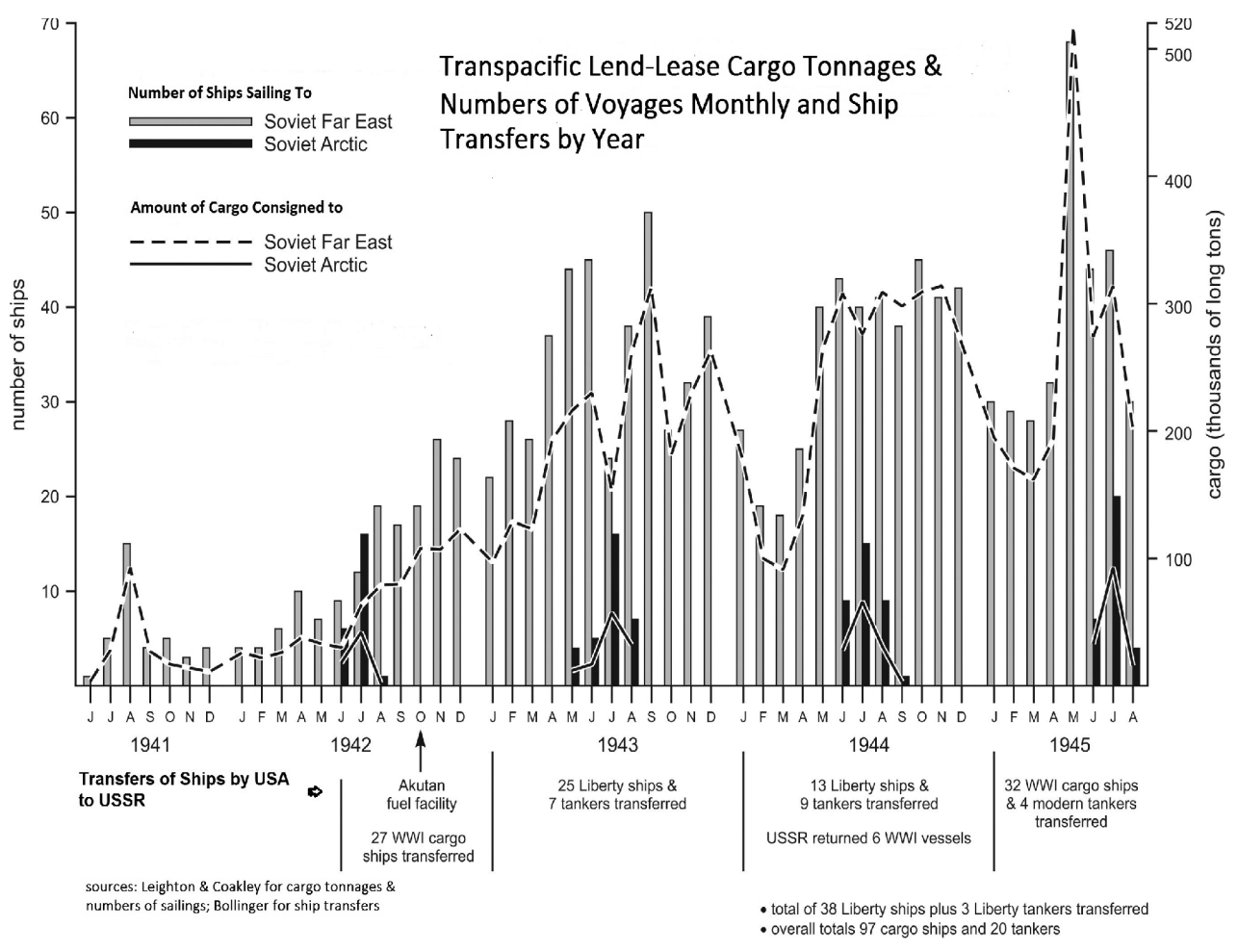

the USSR in May $1943 .{ }^{51}$ Lend-Lease and Mutual Aid freight was consigned to both Canadian and US ports; the first Mutual Aid sailing from Vancouver was in August $1943 .^{52}$

\section{How Transfers of American Tonnage Facilitated the Steady Growth of Cargoes}

The USSR had limited state-owned merchant fleet tonnage because it had largely isolated itself before the war from trading with other economies. It was organized into separate shipping lines by geographic area. The "Far Eastern State Steamship Company" thus became the operator of the shuttle transporting Lend-Lease supplies.

\footnotetext{
${ }^{51}$ James Pritchard, "The Beaver and the Bear: Canadian Mutual Aid, Ship Repairing and the Soviet Far Eastern Merchant Fleet, 1941-1945," Northern Mariner/Le marin du nord XX:1 (April 2010), 38. This article provides useful background on Mutual Aid, as well as repairs to Soviet vessels in $\mathrm{BC}$ and the number of ships that cleared from Vancouver on the Lend-Lease shuttle. ${ }_{52}$ RCN Naval Intelligence Summary 15 Jan 1944, 4; Vancouver was designated by Canadian authorities as the loading port for Lend-Lease cargoes. CNO Intelligence Division Intelligence Report, 9 Nov 1943, 3, LAC, RG 24 Vol 6751 file S-NSS-8001-837.
} 
At the outbreak of war in June 1941 it had eighty-five vessels; the port of registry was Vladivostok. ${ }^{53}$

Shipments of Lend-Lease cargoes from the US to the USSR were modest during the first six months - thirty-seven mostly Soviet ships from the west coast to Vladivostok, and thirty-seven vessels to North Russia from the east coast. ${ }^{54}$ Spurred by President Roosevelt to overcome bureaucratic hurdles, the Lend-Lease program gathered momentum in the United States during the first half of 1942. There were too few Russian vessels to handle the increased supplies awaiting shipment. The Americans started transferring ships to Soviet crews in July 1942 to increase the flow of cargoes across the Pacific. A total of twenty-seven, plus seven tankers, were eventually turned over by the end of the year. These were elderly vessels, mostly recently reactivated ships completed just after the end of the Great War under emergency programs and then laid up for years. ${ }^{55}$ The older tonnage transferred was the best available in mid-1942 because the massive wartime shipbuilding programs were just starting to produce the Liberty ship freighters and their Canadian counterparts and tankers. Cargo capacity was also increased by transferring Soviet merchant ships from the North Atlantic - a small number in 1942, and thirty-three in $1943 .{ }^{56}$

There was a crisis in Allied relations in the autumn of 1942 due to the inability of the US and Britain to supply the promised quantities of Lend-Lease to the USSR, reeling from the German offensive which was advancing towards the North Caucasus and Stalingrad. The situation was brought on by a combination of a growing Allied shipping shortfall and the suspension of convoys to North Russia. The third route for Lend-Lease shipments via the Persian Gulf still had only limited capacity. When notified that the promised deliveries would not be met Premier Stalin eventually proposed in October 1942 that to "relieve the tonnage situation" the quantity of war materials shipped be scaled back in favour of more "pursuit planes", and increased numbers of trucks, aluminum, explosives and grain, which would be shipped by the Vladivostok route provided that the US could transfer twenty to thirty ships. ${ }^{57}$

By early 1943 the Allied shipping shortages were less severe, and the first of thirty-eight newly-built Liberty ship freighters and three Liberty tanker variants (two

\footnotetext{
${ }^{53}$ Paperno, 14.

${ }^{54}$ Leighton and Coakley, Appendix D.

${ }_{55}$ Bollinger, From the Revolution to the Cold War, 148.

${ }_{56}$ 13th Naval District Report 11 October 1943; RCN Intelligence Summary 12 Aug 1943, 12, and 21 March 1944, 17, both LAC, RG 24 Vol 12010 file CNLO 7-2-1 Part 4. recorded that 14 had come through the Canal in June 1943; the total was thirty-three in 1943. The 1942 transfers from the Atlantic had included Uzbekistan which reached San Francisco directly after coming through the Northeast Passage.

${ }^{57}$ Leighton and Coakley, 584, figures on sailings derived from Appendix D. Message from Premier Stalin, Oct 7 1942: Robert Sherwood Roosevelt and Hopkins: An Intimate History, Revised Edition (New York,: Harper \& Brothers, 1950), 639.
} 
of which eventually carried vegetable oils) was transferred direct from the builders' yards. The Liberties were slow and -alarmingly- would prove prone to structural cracking. However, in terms of cargo carrying capacity these 7,176 grt vessels were for their time very capable with five holds, simple cargo handling booms, and modern accommodation. Their largely unobstructed weather deck and generous under-deck areas gave them an "ability to carry a good deadweight of cargo." 58 Liberties became workhorses on the shuttle; it is noteworthy that five of nine freighters that went to the north slope of Siberia in 1944 were of this type; in 1945 it was planned to use ten. ${ }^{59}$

The cumulative Lend-Lease transfers of ships shown in the graph coupled with improvements in turnaround times at both ends enabled a dramatic growth in cargo flow; there was an increase of 41 percent in 1944 over 1943- 2,679,000 compared with 1,892,000 long tons. By June 194468 percent of the Soviet vessels on the trans-Pacific shuttle were former American ships. ${ }^{60}$ Russian carrying capacity almost tripled between 1941 and 1945 due to transfers of American vessels plus transfers from the other Soviet merchant fleets. ${ }^{61}$

The Americans eventually transferred a further thirty-two elderly freighters and four modern tankers in 1945 support Soviet operations being planned against Japan. ${ }^{62}$ Premier Stalin had confirmed in October 1944 that the USSR would attack Japan three months after the defeat of Germany, provided that the US would assist in building up needed reserve supplies. Soviet planners presented a list of items for delivery across the Pacific by 30 June 1945 additional to the current Lend-Lease Fourth Protocol. This new program was termed MILESTONE. Even with some adjustments downward to the list, and to Lend-Lease shipments already planned, the increased requirements posed a challenge for American planners. President Roosevelt pushed hard to get the project underway; MILESTONE was started three months sooner than planned, and in early May when Germany surrendered shipments were not far behind schedule in part due to the additional transfer of ships. $^{63}$

\footnotetext{
${ }^{58}$ L.A. Sawyer and W.H. Mitchell, The Liberty Ships (Colchester, Essex, UK: Lloyd's of London Press, 1985), 24 (the British standard history of this vessel type). The first Russian Liberty captain told author A. Paperno years later "Their operating parameters were unique: their 2,500 horsepower engine consumed only twenty-five tons of oil per day while transporting 10,000 tons of cargo at a speed of 10-11 knots. No other type of vessel since has matched such performance." Paperno, 102.

59 RCN Naval Intelligence Summary t 18 Oct 45, 20, LAC, RG 24 RCN Volume 8142, File 1480-

7 Vol 2; US Report Op-23-Fl21 ARCTIC OPERATIONS 1945, NARA, RG 248/22.

${ }^{60}$ Intel Division CNO Intelligence Report 1 July 1944: "Soviet Mership Fleet 15 June 1944," 1, LAC, RG 25 Vol 6451, file S-NSS-8001-837.

${ }^{61}$ Bollinger, From the Revolution to the Cold War, 149.

${ }^{62}$ Ibid., 162. The fact that these transfers were mostly old tonnage can probably be traced to a renewed Allied shipping crisis in late 1944. C.B.A. Behrens, Merchant Shipping and the Demands of War (London: HMSO, 1955), 409-418.

${ }^{63}$ Coakley and Leighton, 693-697.
} 
Shipments across the Pacific continued after Germany surrendered in May 1945, both to transport supplies already in the procurement pipeline, and under MILESTONE. Lend-Lease to the Soviet Union ended formally on 20 September 1945. However, shipments of items that had still been in the Lend-Lease "pipeline" continued and eventually tapered off in early 1946.

By war's end the United States had transferred 117 ships under Lend-Lease. Forty-six of these ( 47 percent of the tonnage) were new - the forty-one Liberties, plus five of the very capable T-2 tankers. The rest of the transfers were older, mostly Great War era. Twenty of these older ships were returned during the war; four of the 117 transferred became marine casualties, and one was sunk by a US submarine. ${ }^{64}$ The impact of the transferred vessels is underscored by figures from mid-1945 when the War Shipping Agency again noted that Lend-Lease ships were carrying three quarters of the cargoes. ${ }^{65}$

\section{Types of Cargoes}

Military items constituted 20 percent of Lend-Lease aid to the USSR ${ }^{66}$ British historian Richard Overy has written that "the aid that mattered did not come in the form of weapons." Lend-Lease radio equipment enabled the Soviet Army to develop effective Command and Control and battlefield radio intercept systems. Lend-Lease vehicles facilitated its mobility:

One-third of all Soviet vehicles came from abroad and were generally of higher quality and durability, though most came in 1943 and 1944... The list of other supplies, equally vital to the Soviet supply efforts, is impressive- 57.8 per cent of aviation fuel requirements, 53 per cent of all explosives, almost half the wartime supply of copper, aluminium and rubber tyres. Arguably the most decisive contribution was supplies for the strained Soviet rail network, much of which was in the occupied territories in 1941. . Almost half the supplies, by weight, came in the form of food. ${ }^{67}$

\footnotetext{
${ }^{64}$ Bollinger, From the Revolution to the Cold War, 470-473. The ninety-two Lend-Lease ships retained by Russia in 1945 became the subject of prolonged negotiations during the Cold War. Seven modern tankers (four T-2s and the three Liberties) were returned in 1948 along with a vessel built in 1920. The fifth T-2 had broken up in heavy weather off the Aleutians with the loss of sixteen of the crew in 1948 but the two sections were towed to San Francisco Bay. An agreement between the USA and the USSR was finally signed in 1972 under which all articles supplied under Lend-Lease became Russian property in exchange for a payment of $\$ 722$ million. Ibid, 187-190. ${ }^{65}$ RCN Naval Intelligence Summary 31 July 1945, 26, LAC, RG 24 Vol 8142, file 1480-7 Vol 2.

${ }^{66}$ Albert Weeks, Russia's Life-Saver Lend-Lease Aid to the USSR in World War II (Lanham, MD: Lexington Books, 2004), 123.

${ }^{67}$ Overy, 193-97.
} 
The balance included a broad range of items, including relief supplies and blankets. Even a complete Douglas Oil refinery and an electric generating plant were shipped from Los Angeles in mid-1943. ${ }^{68}$

Eastbound ships were mostly in ballast but some brought consignments of furs, chrome, nickel, potash, and surprisingly camel hair - and a bear cub for actor Charlie Chaplin came to Los Angeles in a tanker. ${ }^{69}$ Special cargoes included rough lumber for a US base in the Aleutians and what was officially described as "70 percent pure metal mined near Vladivostok.",70

The transport of the massive quantity of railway stock mentioned above - 1,900 steam and 66 Diesel locomotives and 11,075 flatcars ${ }^{71}$ and rails began in mid-1943; some were occasionally lost over the side in heavy weather. Almost 60 percent of the total shipped went across the North Pacific as deck cargo. This operation required the strengthening of the weather decks of several freighters in west coast shipyards. One of the ports where rails were unloaded was Sovetskaya Gavan on the Strait of Tartary to help build a rail link which was completed in 1945 to the new industrial centre of Komsomolsk na Amure. Discharging at the other end was difficult because of a scarcity of cranes, but at least one ship was fitted in the US with a heavy deck crane. The remainder of the railway stock went through the Persian Gulf. ${ }^{72}$ Finally, shipments across the North Pacific sustained the eastern USSR, including the Arctic coast, replacing foods and other supplies formerly brought from areas devastated by the German invasion. ${ }^{73}$

Military cargo - munitions, half-track vehicles, tanks, shells and anti-aircraft weapons - started being included in trans-Pacific shippings in August 1943, at first via the shallow and difficult Tartary Strait. By 1944 Lend-Lease cargoes included high explosives and amphibious landing craft. The landing craft subsequently proved useful for lightering cargo from ships anchored off Siberian Arctic ports. Patrol torpedo boats (of which sixty-four would be delivered) were reported in October 1944 as consigned for unloading in Petropavlovsk, and off the Amur River. $^{74}$ The freighter Briansk was intercepted by the Japanese in December 1943

\footnotetext{
${ }^{68}$ Eleventh Naval District Intelligence Office Summary for 1943 Soviet Merchant Shipping and Related Activities Los Angeles- Long Beach Area, 16 Feb 1944, 3, NARA, RG 38/52.

${ }^{69}$ District Intelligence Office, 11 th Naval District Summary for 1943, 16 Feb 44, 18, NARA, RG $38 / 52$.

${ }^{70}$ RCN Naval Intelligence Summary 15 Jan 1943, 23, LAC, RG 24 Vol 12010 file CNLO 7-2-1 part 4. Paperno was told about shipments from Siberia of gold.

${ }^{71}$ The rolling stock was constructed in the US to the Russian railroad gauge which is wider than both North American and western European standards. John R. Deane, The Strange Alliance. The Story of Our Efforts at Wartime Co-Operation with Russia (New York: Viking Press, 1947), 95.

${ }^{72}$ Paperno, 265.

73 David Raisman, "The Alaska-Siberia Friendship Route" in Fern Chandonnet (ed) Alaska at War 1941-1945 The Forgotten War Remembered. (Fairbanks, AK: University of Alaska Press, 2008), 342. Raisman was a Russian who cited the impact of Lend-Lease food, medicine, transport and tools in Kolyma and Chukota in the Russian Far East.

${ }^{74}$ RCN Naval Intelligence Summary 20 Oct 44, 31, LAC, RG 24 Vol 8142 file 11961-7 Vol 1.
} 
with a deck cargo of jeeps but allowed to pass. As time went on the Japanese grip on traffic through La Perouse Strait weakened and ships with military deck cargoes used this waterway without interference, even after the USSR denounced the RussoJapanese Non-Aggression Pact on 5 April 1945..$^{75}$ That more than vehicles may occasionally have been involved was suggested in an intercepted telephone conversation in which the captain of a freighter loading in Vancouver BC in December 1943 told a Soviet official in Portland that he had a gun in his deep tank. ${ }^{76}$ Once MILESTONE got underway in 1945, the proportion of military items increased.

The shuttle also transported people and relief supplies for Allied prisoners of war held by the Japanese. The westbound transport of former Soviet soldiers liberated by the western Allies in France began in January 1945. The first load of 600 was carried by one of the NKVD Dal'stroi fleet. The contemporary records and the post-Soviet Russian study by A. Paperno note a total of 3,256 of these unfortunate passengers who faced an uncertain fate. This transport of Russian soldiers continued into 1946 when POWs who had been hospitalized in the US were being repatriated. ${ }^{77}$ Officials and their families coming to North America were eastbound passengers, as were naval personnel in 1945 who were taking over small warships being built in the US and Canada under the MILESTONE project. Starting in October 1943 westbound cargoes also included relief supplies consigned to the International Red Cross and intended for US and Canadian POWs in Japan. ${ }^{78}$

\section{Marine Casualties and War Losses}

Eighteen Russian vessels sank, seven as war losses and eleven as marine casualties. ${ }^{79}$ US submarines sank torpedoed seven Soviet freighters (two in the Sea of Okhotsk and five others off Japan), ${ }^{80}$ and one ship was strafed by an American aircraft near Dutch Harbor in June 1942, when thirteen of the crew were wounded. The Soviet

\footnotetext{
Paperno, 15 for sixty-four PT boats delivered between July 1944 and August 1945.

75 Intel Division CNO Intelligence Report 20 July 1945, 1, LAC, RG 24 Vol 6751, file S-NSS8001-837.

${ }^{76}$ RCN Naval Intelligence Summary 15 Jan 1944, 17, LAC, RG 24, Vol 12010, file CNLO-7-2-1 Part 4.

77 RCN Naval Intelligence Summary, 13 Feb 1945, 28, LAC, RG 24 Vol 8142, file 11960-7 and 6 Feb 1946, 12, LAC, RG 24 RCN Volume 8142, file 1480-7, Paperno, 232.

${ }^{78}$ CNO Intelligence Division Intelligence Report 7 Oct 1943, 3, LAC, RG 24 Vol 6751 file SNSS-8001-837. Japanese ships called at Nakhodka near Vladivostok to load the Red Cross shipments.

79 Paperno, 214-5.

${ }^{80}$ Paperno, 214-5; Bollinger, From the Revolution to the Cold War, 150-1: Angelstroi by USS Grenadier 12 February 1942; Kola by USS Sawfish 16 February 1943; Ilmen by USS Starfish 16 February 1943; Chukcha by USS S-34 31 May 1943 Sea of Okhotsk; Belorossiya by USS Sundance 3 March 1944; Ob by USS Sunfish 6 July 44 in Sea of Okhotsk; Transbalt by USS Spadefish 3 June 1945. Odessa, damaged by an explosion possibly due to torpedoing by USS $S$-44 off Akhomten Bay 4 October 1943, was subsequently sunk by the Japanese 7 October 1943.
} 
freighter sailings were reported to Allied commands; the Americans had "observers" in Vladivostok who normally were not permitted contact with individual ships, but were advised about departures and arrivals. ${ }^{81}$ The Russian vessels were painted grey and carried gun mountings like the wartime merchant ships of other nations. Neutral merchant ships in other theatres with distinctive markings and lighting also became the victims of submarine attacks. The Soviet ships showed running lights while in Japanese waters, but it was apparently not until September of 1943 (after five of the US sinkings) that they began using distinguishing markings on their hulls and large signs on their superstructures. By mid-1944 it was reported that the large Soviet flags painted on the hull were being illuminated, and that the ships were showing three all round green red green masthead lights when west of Akutan. ${ }^{82}$

Given the prevalence of low visibility, generally harsh operating conditions, and lack of radar it is not surprising that there were marine casualties, including collisions, in restricted waters. One vessel was crushed by ice in the Sea of Okhotsk in January 1944; a second sank after an explosion in the Bering Sea in June 1944, and a third foundered in heavy weather off the Kuriles. Eight became total losses after grounding: one each in the Komandorskies, Kuriles and Aleutians (where a freighter grounded in Unimak Pass in November 1942), two on the Siberian coasts, one on Kamchatka, and two on the North American coast. ${ }^{83}$ These latter two losses were small freighters, both northbound from Portland, which grounded in darkness compounded by rain and fog as a storm moved through during the night of $1 / 2$ April. Lamut was driven ashore in gale force winds on the rugged Washington coast south of Cape Alava. Uzbekistan, instead of turning into the Strait of Juan de Fuca for Seattle stood on further north and stranded on southwestern Vancouver Island. ${ }^{84}$ The boarding officers learned about the fate of the masters in three well-known groundings. The captain of Uzbekisan received a conditional sentence of two years. It was said that the captain of Lamut escaped punishment through party connections,

\footnotetext{
81 There were four of five Americans in Vladivostok: diplomats, a naval officer and support staff. They were isolated from contact with locals, not allowed to venture further than nineteen kilometres from the city, and found the atmosphere much less welcoming than that experienced by Allied personnel in Archangel and Murmansk. Kemp Tolley, Caviar and Communists: The Experiences of a US Naval Officer in Stalin's Russia (Annapolis, MD: Naval Institute Press, 1983), 218-9.

${ }^{82}$ Intel Division CNO Intelligence Report, 8 June 44, 1 and 6 Sep 44, 1-2, LAC, RG 24 Vol 6751, file S-NSS-8001-837.

${ }_{83}$ Paperno, 214-5: Total losses after grounding: Turksib in Unimak Pass, 21 November 1942; Bolshoi Shantar in the Kommandorski Islands 13 February 1943; Kherson Kamchatka 23 July 1943; Mariupol in the Kurils 14 November 1943; Shelon off Sovietskaya Gavan 9 April 1944; Kuzbass off Provideniya 26 September 1944; Tmylat lost in storm off Kurils, 11 January 1944; Msta crushed in ice, Sea of Okhotsk, 6 February 1944; Pavlin Vinogradov lost due explosion of acetone cargo, 22 April 1944.

${ }^{84}$ R.E. Wells, The Stranding of SS Uzbekistan (Sooke, BC: self published, 1974), 11-17.
} 


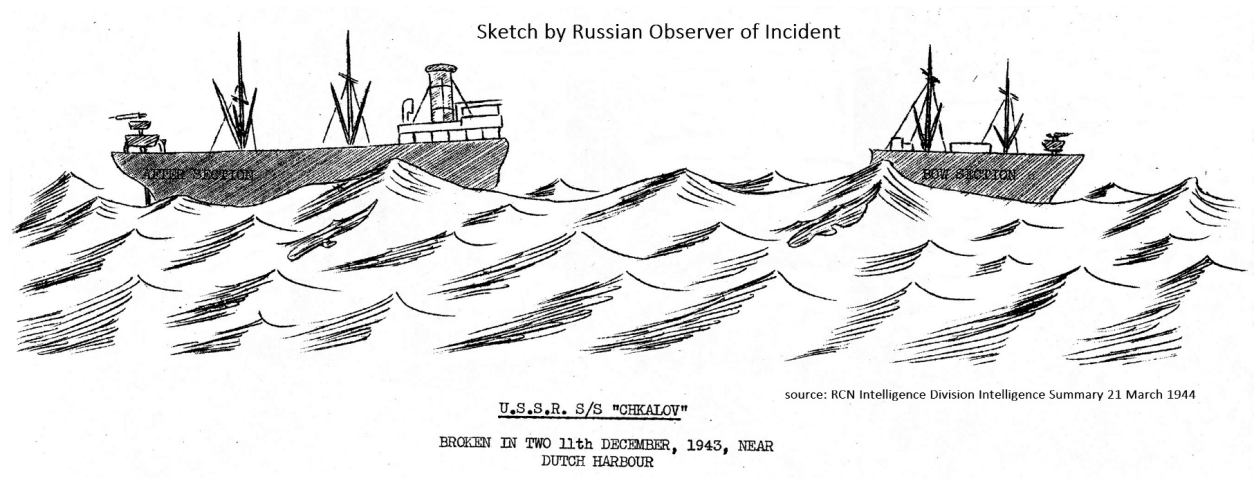

and the captain of a new tanker lost on the Kuriles was given a prison sentence but later pardoned. ${ }^{85}$ The contemporary records are not comprehensive but they noted eight further groundings and collisions.

\section{Hull Cracking in War-Built Ships}

Soviet Liberties began developing hull cracks during their very first winter in operation, 1943/44. At least fourteen of the thirty-eight transferred eventually experienced such damage. (The last one recorded was in February 1946). The most dramatic involved Valeri Chkalov north of the Aleutians in December 1943. Chkalov had been battling storm force 10 and 11 conditions for several days while eastbound in ballast and was listing heavily when with a loud crack like "a cannon shot" the weather deck parted. She eventually broke into two halves, with a lone crew member in the forward section, and the remainder in the stern section. Both were towed to Alaska by a US tug and then to North Vancouver, where they were rejoined in the remarkable time of twelve days. ${ }^{86}$ She then reverted to the American flag and was replaced in the Soviet fleet by another new Liberty. The other Liberties damaged by cracking made harbour and were repaired.

Hull cracks were not confined to Soviet Liberties. The technology of constructing all-welded hulls was new. Such vessels being built in the United States -and particularly tankers and Liberties- had begun developing dangerous hull cracks as early as 1942, and by 1943 intensive investigations were underway. It was determined that cracking was $\mathrm{m}$, repair yards provided them ore prevalent in ships in ballast, and in low temperatures which turned ordinary steel brittle. Because cracks often started in stress areas around hatches special reinforcement along with

\footnotetext{
${ }^{85}$ RCN Naval Intelligence Summary 22 Jan 45, 31, LAC, RG 24 Vol 8142 file 11961-7 Vol 1.

${ }^{86}$ The crew member in the forward section was without food or water for three days. Merchant Vessel Boarding Report JAN JORRES, no date but boarding was on Dec 26, 1943, LAC, RG 24 Vol 11919; RCN Intelligence Summary Report of Interrogation of Masters Russian Ships, 21 March 1944, 17, LAC, RG 24, Vol. 12010, file CNLO -7-2 -1 part 4; Pritchard, "The Beaver and the Bear," 135.
} 
strengthening the area where hull and deck plating met with riveted gunwale bars. Twenty-eight Soviet Liberties had their hulls strengthened in North Vancouver in 1944 with riveted plates fore and aft, and riveting angle irons at deck level, a process apparently requiring five to six weeks. ${ }^{87}$ At least three Liberties due to carry cargoes to the Arctic also received ice strengthening and additional heating in their accommodation spaces. ${ }^{88}$

A postwar report found that about one in five of the merchant ships built in the United States suffered some form of structural failure; exhaustive investigation concluded that culprit was metallurgical failure due to the use of steel that had not met the prescribed standards. Such problems in thirteen of the thirty-eight Soviet Liberties probably reflect the fact that these ships regularly made voyages in ballast in heavy seas and operated in cold temperatures. ${ }^{89}$

The Soviets were responsible for consigning Lend-Lease cargo to individual ships but US officials became concerned in 1943 on the basis of direct evidence and telephone intercepts that masters were overloading their ships. WSA correspondence from San Francisco War to Washington in December 1943 reported: "Our Russian friends started loading the Liberties with about 9,200 tons. They crowed when they loaded 9,400 tons. They smiled smugly when they loaded 9,600 but believe it or not, they loaded 9,956 long tons on the KUBAN which sailed from here recently. She was well over her marks, as you can imagine, but it doesn't seem to bother them any. ${ }^{900}$

The motives might have been a combination of wanting to over-achieve the prescribed "norms," ${ }^{91}$ pressure from the Soviet shipping officials in the United States pushing to expedite cargoes, ${ }^{92}$ and possibly patriotic urges. A periodic US

\footnotetext{
${ }^{87}$ Vancouver Merchant Ship Boarding Report JAN JORRES, 5 Apr 1944, 2, LAC, RG 24 Vol 11891 NFM Russian Ships; RCN Intelligence Summary 1 May 1944, 9, LAC, RG 24 Vol 8142 file 11961-7 Vol 1.

${ }^{88}$ Paperno, 109, 117, 118. This appears to have been minimum strengthening as the work was said to require only two days.

${ }^{89}$ Sawyer and Mitchell, 11; Francis Mansbridge Launching History The Saga of Burrard Dry Dock (Vancouver, BC: Harbour Publishing, 2002), 93; Peter Elphick, Liberty: The Ships that Won the War (Annapolis, MD: Naval Institute Press, 2001) 145, 159-177.

${ }_{90}$ War Shipping Administration memoranda and letters dated December 8 and 9, 1943, undated Interoffice memorandum apparently dated August 1944, letter dated September 2, 1944. All in RG 24/21, NARA.

${ }^{91}$ In mid-1945 several Russian masters told boarding officers at Dutch Harbor that they hoped a mid-voyage fuelling station would continue to be available because it enabled them to sail from the west coast with less than full fuel tanks which meant that they could load more cargo. This increased their opportunities to over-fulfill their yearly "plan." 17th Naval District Kodiak District Intelligence Office Report on Vessels Boarded 11-17 Nov 1945, 3, NARA, RG 38, ONI Administrative Correspondence 1942-46.

92 War Shipping Administration correspondence in RG 248/21, NARA; reports on intercepted telephone conversations in same file. Two (Office of Censorship United States of America, dated December 2 and 12 1943) concern calls by a Russian official of the Soviet Purchasing Commission office in Portland to masters of two freighters loading in Vancouver, BC. In both cases the official tried persistently to convince the masters to load to 9,400 tons. Both masters said they would take
} 
Navy Intelligence summary in February 1944 noted that four of the eight Liberties that had suffered hull cracking in the North Pacific that winter had sailed from the west coast overloaded..$^{93}$

\section{Repairs and Overhauls in US and Canadian Ports}

The small prewar Soviet merchant fleet in the Pacific had relied largely on repair yards in China because the infrastructure in the Russian Far East was quite limited and engaged on naval work. ${ }^{94}$ During the early months of the shuttle it became apparent that many of the Soviet ships required extensive refits in addition to repairs from ice damage. The greatly expanded wartime fleet came to be supported on the west coast of North America. ${ }^{95}$ To supplement American resources the United States Maritime Commission arranged for repairs in Vancouver starting as early as March 1942. Their costs were funded by Canada as part of Mutual Aid. ${ }^{96}$ By January 1945 Akutan was reporting that twenty of the twenty-three recently-arrived ships were to have repairs of some sort on the west coast. ${ }^{97}$ The refits funded under Lend-Lease were not limited to vessels in the shuttle. Small freighters normally used in coastal trades in Siberia crossed the ocean for overhauls, along with a crab fishing and processing fleet which had some of its vessels replaced by ships in better condition fitted with new processing equipment. ${ }^{98}$ The extent of ship repair under Lend-Lease and Canadian Mutual Aid is outside the scope of this paper but it included work

only 9,000 because a portion of their cargo was heavy. One was told about Liberty ships loading to 9,400 tons in other ports; one of them was told "it will mean unpleasantness for you." Both resisted robustly, one saying that "I'm the Captain and that's why I can't risk my ship ....if another Master took 9,400 tons that is his business, not mine" and the second master saying that he would hate to lose his entire cargo for the sake of 132 trucks. Intelligence based on intercepted telephone calls also crops up in RCN Intelligence Summary 15 January 1944, 17, LAC, RG 24, Vol. 12010, file CNLO -7-2-1, part 4 which cites information gleaned from a telephone intercept about the grounding off Provideneya in heavy fog in August 1943 of the Liberty Voikov.

93 Intel Division CNO Intelligence Report 7 Feb 44, para 1, LAC, RG 24 Vol 8142 file 1480-7 Vol 2. B.

94 CNO Intelligence Division Intelligence Report 15 Aug 1943, 1, LAC, RG 24 Vol 6751 file SNSS-801-837.

95 Pritchard, "The Beaver and the Bear," 142, observes that by February 1945 repairs in BC ports had reached an all-time high, had spread to Victoria and Prince Rupert, and were monopolising virtually all ship repair resources in the province.

${ }^{96}$ Pritchard, "The Beaver and the Bear", 133; J.S. Marshall, J.S. A History of Burrard Dry Dock Company (Vancouver: Burrard Drydock Company, 1960), III:193; James Pritchard, A Bridge of Ships: Canadian Shipbuilding during the Second World War (Montréal and Kingston: McGill Queen's University Press, 2011), 115-116.

97 Akutan report 24 Jan 45, 3 NARA, RG 38/52.

${ }^{98}$ CNO Intelligence Division Intelligence Report 15 Aug 1943, 1; possibly the smallest vessels overhauled under Lend-Lease were four two-masted wooden auxiliary schooners which crossed the ocean in December 1943. CNO Intelligence Division Report 3 Dec 1943, 3; both LAC, RG 24 Vol 6751 file S-NSS-8001-837. 
such as the overhaul of the new Soviet Liberty Voikov which had grounded near Providenya in August 1943. After being towed free she had temporary repairs there and then did an epic voyage across the North Pacific to Seattle partially under her own power and partially in tow by a second Liberty. ${ }^{99}$

\section{The Role of NKVD-Operated Ships and Troops}

The NKVD, the Soviet state's law enforcement agency, played important roles in the Lend-Lease saga. ${ }^{100}$ Siberian gulag camps, including the Kolyma gold mining operations north of Magadan, were run by "Dal'stroi", an acronym for the "Far Northern Construction Trust," the special industrial organization subordinate to the NKVD. Five of its ships normally used to support this operation became involved in the trans-Pacific shuttle and were refitted on the west coast. ${ }^{101}$ The NKVD subordination of these vessels was reported matter- of- factly in US and Canadian reports. Soviet masters remarked that unloading in Nagaevo (under NKVD control as the port for Magadan) was more efficient than elsewhere, that it was one of the most modern towns in the Russian Far East and that it offered welcome amenities for crews. At the same time it was reportedly "known locally and unofficially as the "Convict Republic." 102 In the summer of 1944 Soviet naval security guards in the Vladivostok port area were apparently replaced by NKVD troops to reduce smuggling by ship's crews and an increase in pilfering by port workers, which in one case amounted to 33 percent of the cargo. ${ }^{103}$

\section{Observations about Crews by US and Canadian Boarding Officers and in Post- Soviet Accounts}

The US and Canadian boarding officers collected observations about Russian crews in their interviews with ships' captains. Although at least one ship had a female

\footnotetext{
${ }_{99}$ RCN Intelligence Division Intelligence Summary, 1 Dec 1943, 1, LAC, RG 24 Vol 12010 file CNLO 7-2-1 Part 4.

${ }^{100}$ NKVD became the KGB during a restructuring in 1954 and was again restructured when the USSR ended. Today's Russian FSB has inherited much of the KGB's state security role.

${ }^{101}$ Martin J. Bollinger, Stalin's Slave Ships: Kolyma, the Gulag Fleet, and the Role of the West (Annapolis, MD: USNIP, 2003), 39.

${ }_{102}$ RCN Intelligence Summary 20 Oct 1944, 24, LAC, RG 24 Vol 8142, file 11961-7 Vol 1. In October 1944 boarding officers in Akutan were told that 2,000 prisoners had recently arrived by sea in Nagaevo in Minsk, one of the Dal'stroi vessels that made several Lend-Lease crossings. The prisoners, including 500 women, had been convicted of collaborating with the Germans. Another 1,000 passengers were said to be coming to work of their own accord in the Kolyma gold fields. 17th Naval District Kodiak Report on Soviet Vessels Boarded Akutan Oct 7-12 1944, 2, NARA, RG 38 ONI Administrative Correspondence 1942-46.

${ }^{103}$ RCN Intelligence Summary 15 Aug 1944, 2, LAC, RG 24 Vol 12010, file CNLO 7-2-1 part 4.
} 
master, the dynamic Anna Shchetinina, the world's first female merchant ship skipper, most of the females appear to have been stewardesses and catering staff, and some female mates and radio officers were also noted. ${ }^{104}$ There were occasional births on the high seas, and at least one in a Vancouver hospital. A few captains were accompanied by their wives (a perk which ended after the war), and one ship carried classes of trainees from a Vladivostok nautical college. ${ }^{105}$

Canadian boarding officers on occasion helped deal with indiscipline in merchant vessels under the Canadian and other flags. ${ }^{106}$ These were former civilian mariners familiar with merchant ship crews. They were impressed by the discipline of the Soviet crews who were often young and inexperienced. For example, a Russian master reported in Vancouver in September 1943 that his complement of forty-seven men, six women and eleven naval gunners was young and unseasoned. The Soviets handled any crew problems internally. The impressive conduct ashore and discipline of the crews reflected the all-pervasive internal security structure of the USSR. Crew members were aware that the NKVD had informants in their midst. It was not until after the war that American and British codebreakers deciphered Soviet message traffic showing the extent of NKVD surveillance of Russians abroad during the conflict. The intercepts recorded that the crew of every merchant ship calling in the west for Lend-Lease supplies included between one and three informants who reported to the NKVD or the Naval Intelligence Service (Naval GRU). Their role was to watch their fellow crew members, not to spy in the US or Canada. ${ }^{107}$ The ships carried a Pompolit or "Political Assistant," often listed as an extra mate, who was responsible for political indoctrination and discipline. ${ }^{108}$ The US and Canadian boarding officers started asking questions about the role and identity of the Pompolit starting in1945, but were never quite able to establish

\footnotetext{
${ }^{104}$ She commanded two freighters during the war including a Liberty and continued her seagoing career afterwards. She became a celebrity in the USSR and published her memoirs in 1976. Paperno 113-125 The boarding reports show that Captain Shchetinina was cooperative and informative.

${ }^{105}$ RCN Intelligence Report 18 Oct 1945, 10, LAC, RG 24 Vol 8142 file 1480-7 vol 2.

${ }^{106}$ Frederick Watt, In All Respects Ready: The Merchant Navy and the Battle of the Atlantic, 19401954 (Scarborough, ON: Prentice-Hall, 1985). Watt was with the Naval Boarding Service in Halifax and describes its work with merchant ship crews.

107 John E. Haynes and Harvey Klehr, Venona: Decoding Soviet Espionage in America (New Haven and London: Yale University Press, 1999), 21. The Venona Project began in 1943 and ended only in 1980. It remained secret for fifteen years after it concluded, having revealed Soviet espionage of the Manhattan Atomic Bomb Project and the existence of the "Cambridge Five" spies.

${ }_{108}$ The earliest mention of a crew member responsible for discipline and political education was by a US boarding officer in August 1943. CNO Intelligence Division Report, 7 October 1943, LAC, RG24, Vol 6751, file S-NSS-8001-837. In February 1945 a Canadian boarding officer in Vancouver (a native speaker) was told that Pompolits had been re-introduced in ships going to the west coast because of recent desertions by officers and men. Staff Officer (Intelligence) West Coast letter to Director Naval Intelligence, 20 Feb 1945, LAC, RG 24, Vol 12010 CNLO-7-2 Part 6.
} 
whether this was a collateral duty assigned to an extra qualified mate or engineer or whether these were not genuine mariners.

A Canadian naval intelligence officer in Vancouver reported in July 1944 that other than masters' Soviet crews were permitted to go ashore only in groups of three or more, were responsible for each other's conduct, instructed to not to accept private hospitality ashore or to visit homes, not to speak with strangers, and even not to acquire or use printed matter ashore. ${ }^{109}$ Russian researcher A. Paperno was told by veterans about group excursions in US ports organized by local Soviet officials. These were obviously welcome for men with very limited funds and little or no English but they were also a form of control.

A small number of deserters and other incidents ashore were recorded. ${ }^{110}$ One seaman was reported as having deserted in May 1944, and a second in February 1945 was sheltered by a girlfriend and enlisted in the US Army. ${ }^{111}$ A Seattle newspaper reported at the time that there had been eight to ten desertions during the war. The master of a ship that arrived in Victoria for repairs in May 1944 also deserted. ${ }^{12}$ A more tragic case involved a deserter who committed suicide in July 1945 while in hospital after serving in US merchant ships. ${ }^{113}$ In what the author characterizes as a "mass exodus" Alla Paperno notes that three officers, two motormen and a female crew member deserted in Vancouver in 1942 from a ship completing an overhaul. The chief officer came to suspect that his captain, an old friend, was acting as an agent provocateur for the NKVD. ${ }^{114}$ These individuals are a tiny fraction of the Russian crews who visited west coast ports.

\footnotetext{
${ }^{109}$ Letter from Staff Officer (Intelligence) Vancouver to British Naval Liaison Officer San Francisco 18 July 1944, LAC, RG 24 Vol 8142 file 11961-7 Vol 1.

${ }^{110}$ US Immigration permitted four Russian merchant seamen deserters in Seattle to sign on as crew of a vessel of a second foreign country in 1944. When thus vessel returned to the US the Russians would be allowed ashore like the other crew members but would not be permitted to return as permanent residents. Letter from Cdr Little, DNI to A. Joliffe of Department of Immigration Ottawa 4 Oct 1944, LAC, RG 24 Vol 8142 file 11961-7 Vol 1.

${ }^{111}$ RCN Intelligence Summary 13 Feb 45, 20, LAC, RG 24, Vol 8142 file 11961-7 Vol 1.

112 RCN Intelligence Summary 15 Aug 1944, 21, LAC, RG 24 Vol 12010, file CNLO 7-2-1 Part 4.

113 RCN Naval Intelligence Summary, 15 Aug 44, 21, LAC, RG 24 Vol 12010 file CNLO 7-2-1 Part 4; 31 Jul 45, 20, LAC, RG24 Vol 8142 file 11961-7 Vol 1.

114 Paperno, 248. This "mass exodus" was from Sovietskaya Latvia, completing a long overhaul. The wife of the fourth engineer had given birth to a daughter in a local hospital; he decided to stay behind with his family and was followed by the other deserters. The ship's political officer lost his position on return to Russia. This is a poignant story because the captain fell under the NKVD's suspicion. He had been able to have an operation for a back problem said to be unavailable in the USSR in a Vancouver hospital thanks to help from two Russian émigrés he had befriended. His chief officer, an old chum had written to another buddy, the captain of a ship undergoing repairs in Seattle that the recently-hospitalized captain had ruminated about wanting to stay in Canada. The suspicious letter writer took the remark by his captain as one designed to cause him to make a similarly disloyal observation and took it as a sign that their friend was reporting for the NKVD. He unwisely reported this assumption in his letter to Seattle. The captain who had been in Seattle later perished at sea during the war. Some years later, in 1948 the letter writer was summoned by the NKVD who were investigating his former captain who had been hospitalized in Vancouver.
} 
The records show that at the working level most Russian masters were cautious in their dealings, reflecting their years under the oppressive and omnipresent Soviet internal security apparatus, in combination with a traditional national distrust of foreigners. Attitudes on both sides also changed as the trans-Pacific shuttle developed. The Americans found that the officers in eight Soviet merchant ships who reached Seattle in January 1942 "seemed to be cooperative and answered questions promptly and apparently without any attempt to be evasive." 115 However, Soviet liaison officers soon appeared in west coast ports who insisted on being present when ships' captains were interviewed, and restricted how much information was provided. ${ }^{116}$ Privately some masters expressed disdain for these shore-based officials. Masters were now occasionally grudging in providing information beyond weather conditions encountered. Information was given more freely at Akutan and Dutch Harbor where there were no Soviet liaison officers. After the defeat of Germany, Soviet masters interviewed at Akutan foreshadowed Cold War official attitudes. They reported that tensions might arise between the USA and the USSR, the only truly Great Powers. Propaganda at home was describing the United States as being divided into "good/liberal" and "bad/anti-Soviet reactionary" camps. ${ }^{117}$ Despite the constraints on how freely Soviet captains spoke, an impressive amount of detailed information was accumulated over hundreds of boarding interviews.

\section{Conclusion}

The success of the massive trans-Pacific shuttle was due to collaborative efforts by the Americans, Soviets, and, on a more modest scale by Canadians, to overcome bottlenecks and improve cargo flow. Over time Lend-Lease shipments across the Pacific outpaced those via the Persian Gulf and to North Russia. Half of the wartime supplies provided to the Soviet Union were transported in what was developed into an important strategic route. Contemporary records provide a detailed picture of the challenges that arose and of how they were overcome. They confirm that the cargoes included military supplies after August 1943.

The consistently high priority assigned by President Roosevelt for aid to the USSR was reflected in how US officials were constantly engaged in stepping up shipments. When it became obvious very early that the Russian merchant ships in the Pacific required extensive refitting and repair, the Americans started to augment their own limited repair capacity by using BC shipyards for this work. The US also created a fuelling base in the Aleutians for the Soviet shuttle, and helped to upgrade

\footnotetext{
115 Staff Headquarters 13th Naval District Seattle letter 2 Feb 1942, 2, NARA, RG 38/52.

${ }^{116}$ CNO Intelligence Division Intelligence Report 6 Apr 1943, 3. A Lieutenant Pavlov of the Soviet Navy arrived in Vancouver in October 1943. Staff Officer (Intelligence) Vancouver letter 14 Oct 1943, LAC, RG 24, Vol 11891, NFM Russian Ships.

${ }_{117}$ RCN Naval Intelligence Summary Report 18 Oct 1945, 11, LAC, RG 24 Vol 8142 file 1480-7 Vol 2.
} 
port and rail infrastructure in the Soviet Far East. When available cargo outpaced Soviet shipping capacity in 1942 the US started transferring ships to Russian registry. By 1945 former American vessels were carrying more than three-quarters of the tonnage flow across the Pacific.

Soviet vessels made more than 1,400 voyages, including 124 from Vancouver, with Canadian Mutual Aid. ${ }^{118}$ In addition there were 140 sailings directly from the west coast to the Siberian Arctic. ${ }^{119}$ It is noteworthy that in the Pacific Lend-Lease, in addition to supplying war material, raw materials, foodstuffs and clothing, and the majority of the vessels involved, also facilitated Russian projects to create a modern port at Petropavlovsk, to upgrade the infrastructure in Vladivostok, and to extend the Siberian rail network.

\footnotetext{
118 Pritchard, A Bridge of Ships, 116.

119 Derived from Coakley and Leighton Appendix D and Richard M. Leighton and Robert W. Coakley Global Logistics and Strategy 1943-45 (Washington, DC: Office of Chief of Military History, 1968), Appendix G-3.
} 